DOI: 10.1515/ausp-2015-0038

\title{
The Image of the East-Central European in Rose Tremain's The Road Home
}

Food, Materialism and Capitalist Faith in a Culture Clash

\author{
Ágnes HARASZTOS \\ Eötvös Loránd University (Budapest, Hungary) \\ Department of English Studies \\ School of English and American Studies \\ anyiszja@gmail.com
}

\begin{abstract}
In Rose Tremain's The Road Home, the culture clash of the British and the East-Central European is portrayed through a complex symbolism centred on images of food, consumption and waste. This literary representation may shed light on British literary auto-images, as well as hetero-images of the Eastern European immigrant. The novel's presentation of this culture shock is defined by the cultural historical and economic circumstances of the parties. Food and material provide the symbolic sphere where the relationship between Britain and East-Central Europe is characterized in terms of capitalist worldview as opposed to a post-communist existence. William Shakespeare's Hamlet is the most important intertext for Tremain's novel. Hamlet is obsessed with the vulnerability of material in light of the spiritual value attached to it in the form of human soul. Stephen Greenblatt's ideas on food, waste and the Christian belief in divine existence residing in material objects - ideas that originate in early modern times - shed light on the motif of material and food in The Road Home. Seen through the symbolism of food and the idea of differing values being attached to matter, the narrative identity of Lev, the protagonist of Tremain's work, experiences drastic change due to his encounter with the capitalist, British 'other'.
\end{abstract}

Keywords: British East-Central Europe novel, symbol of food, Tremain, Greenblatt, capitalism, material, representation

\section{Introduction}

Contemporary British novels about East-Central Europe rarely display such an intricate symbolic web in presenting the figure of the East-Central European as Rose Tremain's The Road Home. This work is rich in symbolic representation of the British East-Central European culture clash drawn from the field of food, matter, waste and artistic representation. All these symbols can be understood 
from the background of the cultural-economic dichotomy of capitalist and postsocialist countries.

Lev, the protagonist, who has an unspecified East-Central European identity, is an intertextual kin to Hamlet. Lev is on the borderline of eras and cultures and this makes him resemble the original Shakespearian character. Apart from overt intertextual links, the mutual abhorrence at certain aspects of matter strikingly binds the hero of Shakespeare's Hamlet to that of Tremain. Stephen Greenblatt wrote about this issue in the context of a Renaissance religious anxiety concerning spiritual value attached to food and material (Greenblatt 2000). His suggestions about the quasi-religious aspect of modernity and capitalism have a lot to reveal in connection to the imagological issues of Tremain's novel. Throughout the painful evolution of the East-Central European hetero-image, The Road Home also presents a critical view of the British. All this is embedded in the symbolism of food, consumption and waste endowed with divine, spiritual or aesthetic value. While the reader gains insight into the novel's presentation of the Eastern-European, fundamental questions arise with regard to the difference between the British and the East-Central European, and respectively, the capitalist and the post-socialist ways of thinking inherent in the cultural codes of the different economic systems.

\section{Capitalism as a miracle for post-Socialist societies}

Lev, the 42-year-old economic immigrant, arrives in Britain having just survived the severe emotional crisis of losing his wife. He works in a posh London restaurant and sends money home to his small daughter and elderly mother. Through the narrative, he comes to admire elegant and modern cuisine. He becomes very much obsessed with the "beautiful food" he never experienced at home. His dream is to open a modern restaurant in his hometown to show people there that special food, prepared with meticulous care and served elegantly gives pleasure, even happiness. All this stands in symbolic opposition to "Communist food" characterized by "stained tablecloth," "unidentifiable stew" and waiters who behave like "labourcamp guards" (Tremain 2007, 39). Consequently, the image of food gains the role of representing the symbolic chasm between "the culture of plenty and the culture of want," as expressed by Anna Maria Tomczak (Tomczak 2013, 457).

Food that lacks in poor countries and that abounds in rich countries is and has traditionally been the most important motivation behind economic migration. Food as a symbol has centuries-old roots in European capitalist ideology that dates back to the cradle of modernism and rationalism, that is, the Renaissance. In relation to Shakespeare's Hamlet, Stephen Greenblatt calls attention to early modern religious anxieties concerning Real Presence in the Holy Communion 
and, consequently, material in general. In Shakespeare's time, Catholic and Protestant debates about the Holy Communion savoured the rising ideology of secular materialism. Catholics believed that the material of the bread, after transubstantiation, is one and equal to the body of Christ, whereas, Protestants regarded the Eucharist as a representation. This had further consequences and anxieties regarding the journey of Christ through the material from the mouth to the bowels and onwards (Greenblatt 2000, 150).

The continued belief that products of the human brain (materialized) can appear as independent beings endowed with life of their own influences the formation of $19^{\text {th }}$-century consumer capitalist ideology. Greenblatt cites Marx here who argued that capitalism resembles Catholicism in this respect. Marx illustrates this with the ontological sameness of the statement "This bread is the body of Jesus Christ" versus "This bread is five pennies." Both are ideas requiring faith with grave consequences to practical life. Capitalist social order should be credited (paper money is one emblematic instant of this), otherwise it breaks down into chaos (Greenblatt 2000, 166). The gesture of faith, or rather credit, a suspended version of faith, that material is more than what meets the eye is essential to capitalism.

This quintessential element of capitalist economic and cultural systems captures Lev's imagination in modern British cuisine. To him, what GK Ashe performs in the kitchen is a miracle that turns the base, lowly material into "most delicious combinations that the human mind is capable of inventing" (Tremain $2007,101)$. The fact that it is then called by some posh French name strengthens its transubstantiation. Lev realizes in London that food can be much more than simple nourishment for the body. Served and prepared in a way nearing art, food can be "refreshing," "delicate," and even "beautiful” (Tremain 2007, 76-78). The terms with which he describes modern British meals create an atmosphere which suggests that entirely new feelings, such as respect, awe or admiration are aroused in Lev for the dishes themselves.

This transubstantiation of matter is what Lev intends to bring to his poor postCommunist country. However, he still has to convince his own home culture. As a postmodern, Eastern European Hamlet, he continues conversing with his deceased father's spirit. Lev remembers his father saying "things can only be what they are" (Tremain 2007, 78). In light of Lev's inner turmoil of newlyfound culinary realizations in the narration's present, this flashback settles the dichotomy of the two worlds. Britain and East-Central Europe differ with respect to a fundamental attitude to faith in value attached to material. In the representation of the novel, East-Central Europe lacks the capability of believing in miracles that turn one thing into another. It may be called pessimism or scepticism. The great extent to which post-socialist societies got accustomed to not being the master of their own lives is illustrated by the words of Ina (Lev's mother): "what's the point of it [caring about anything - Á. H.] when 
life takes everything away?" (Tremain 2007, 7). In contrast to this characteristic apathy, Lev seems to take on the role of the optimist dreamer. His character is the most open-minded East-Central European figure of the novel who has a natural aptitude to what is portrayed as a Western, capitalist self-fulfilling faith. A faith which, by its very existence, engenders the working of systems let that be either religious, economic, social, or art systems. ${ }^{1}$ Although, Lev is, from the beginning, inclined to adopt the capitalist type of faith in the symbolic value of material, his conversion happens in a painful and shocking way.

\section{Anxiety of waste}

The Road Home presents a development of Lev's narrative identity which may be appropriated to what the study of imagology calls the effect of the auto-image on the hetero-image. This novel may be considered, to some extent, a Bildungsroman. Although, Lev is not a classic youth who achieves adulthood through a series of adventures, he achieves some maturity indeed which leads him to new and lifechanging inferences. His personal development models after a typical pattern in such imagologically-marked novels which may be termed 'the effect of the other.' In this pattern, as it was described by István Fried, the protagonist's waking up to a wider cultural reality happens through the influence of another particular culture (Fried 2012, 209). The 'other' in the British characters broadens the view of Lev to a more general, Western way of thinking.

Throughout this guided development, the fictional East-Central European immigrant becomes at once privy to and the victim of some of the most controversial social and cultural phenomena with which the British are forced to live. In The Road Home, we receive a fully-fledged tableau of British society, where dirty work with the disgusting aspect of matter is mostly done by sociallymarginalized figures, foreign immigrant workers. Lev works at a kitchen sink, his Irish friend is a plumber and one certain East-Central European character expresses the statement that to the English, we as bodies are a "mystery and terror" (Tremain 2007, 96).

It seems that this Western world into which Lev is thrown has problems when facing the decomposition of matter. This phenomenon may be explained by Greenblatt's ideas on the Renaissance-originated modern anxieties regarding

1 In fact, post-socialist societies are capable of belief, only that it is restricted to a traditional, magical, and more passive religious stance. Corresponding to this kind of belief, in the world of the novel, Eastern-Europeans have a tendency to expect miracles without their active intervention. An example of the attitudes the two distinct types of faith give rise to is how Rudi and Ina passively wait for something to happen or someone to intervene, as opposed to Lev who mostly aspires to influence his own fate. In order to fully realize this dream, he needs to encounter the West. 
the vulnerability of the material which carries divinity. The early modern religious tracts were most puzzled by the issue of how to account for the body of Christ in excrement. Waste as the civilizationally shameful and disgusting side of human body was debated to have been elevated by eating Christ's physical body (Greenblatt 2000, 147). Greenblatt argues that there is a hidden Protestant polemic against the Catholic Eucharist in Shakespeare's Hamlet. Hamlet's sceptical, secular doubts about the possibility of divine presence in the endlessly circulating, decaying material are pointed with abhorrence against the Catholic discourse of suspended disbelief (Greenblatt 2000, 153). However, the alwayshesitating Hamlet is rather puzzled by the coexistence of belief and disbelief in his own mind. He is preoccupied with the physical law that resists any selffulfilling belief. No matter how strong Catholics believe, it does not preserve the transubstantiated bread from decay. Hamlet is famously lost on the verge of two worlds which later became the very root of Western civilization with all its doubts and anxieties. It seems that abhorrence at excrement and waste has been an integral part of Western culture ever since the Renaissance. The early modern religious debates created a secular world at once discarding and keeping some aspects of faith. This world persists in being embarrassed by human filth.

The Road Home presents this Western attitude in the form of a social critique, where British society chooses to avoid any dealings with waste, leaving it to immigrants. As opposed to the English civilizational attitude to the dark side of flesh, body, and finally food, Lev repeatedly expresses that he has no problem cleaning the toilet or washing vomit. Cleaning his ill wife's vomit, to him, is "part of her, everyday human mess, a sign that his wife was still alive" (Tremain 2007, 86). He does not share Western anxieties concerning the waste, because for him, material is not yet endowed with spiritual value.

In imagological terms, this contrast may be called the age-old nature-culture dichotomy. Moreover, this dichotomy may also be explained by the presence or lack of the early modern originated, later capitalist faith in the spiritual value of the matter. East-Central Europeans are represented in the novel as people to whom matter is matter and it carries no other significance or meaning that would link it with values or lack of values.

\section{Food, body, sexuality}

Abhorrence at human excrement has become the indicator that Western culture has endowed material with spiritual value. Christians have taken part in God's mystic life for centuries through eating his body as a meal. However, the Western world associates excrement with evil, because it is the despised other end of the same process. Food associated with the positive pole of physicality, and waste 
with the negative is a classic symbolism. In The Road Home, food also appears as an archetypical form of matter: flesh and body. The metaphorical link between food and sexuality is age old and it has defined centuries of British literature as well. The Road Home's Shakespearean intertext, Hamlet also abounds in linking food and sexuality. Instances of this range from the gustatory "rottenness" linked to Gertrude's sexual appetite that disgusts Hamlet to the association of sexuality and eating rubbish (Greenblatt 2000, 156).

Rose Tremain's narrative style is also rich in metaphorical language revolving around the image of food. Lev and Sophie's relationship from beginning to end is especially defined by images of food and eating. At the dawn of their love affair, both are drawn towards each other by a mere sexual attraction characterized by appetite. Sophie's first violently devouring kiss is described thus: "he saw her mouth open and waiting" (Tremain 2007, 121). Later also, Sophie often refers to Lev as a delicious dish. Lev also expresses his desire in culinary terms, he often describes his English lover in gustatory terms, likens her to a delicious meal and finds her tasty: "she is like some exotic dish that I don't yet know how to make but yearn for in my dreams" (Tremain 2007, 176).

In terms of sexuality, the metaphor of food consumption carries the meaning of exploitation. Lev's relationship with the English Sophie is paralleled to his immigrant existence: being economically exploited and treated as mere flesh in bed gradually become interconnected. The text links Sophie's exploitation of Lev's sexual performance to his being exploited at his workplace. Both processes render Lev an animal. There is a parallel in textual references to Lev's exhaustion likened to a mule and his post-coital exhaustion when "he fell forwards on her, like an animal, spent and dying” (Tremain 2007, 193).

This link between food and sexuality leads to a more general understanding of the process of evaluation, and even more generally the appropriation of value to material. As Hamlet links eating rubbish to filthy sexuality, Tremain's novel also plays with attaching ways of eating to stages of Lev and Sophie's sexual relationship. At a turning point of their affair, Lev tells her the story of his arrival in England. Then he associates his initial loneliness with eating a hot-dog alone. By this time, Sophie seems to be tired of Lev's narratives and her position in it, so she attempts at laughing off Lev's wistful memories by a derisive remark about how heartbreaking it all is. After this, Lev feels dumbed: "He knew that Sophie had said something he should probably be laughing at, but he didn't know what it was. [...] He stared at the seagull cramming its sharp beak with the dropped food. [...] He sensed that something fundamental about the day had changed" (Tremain 2007, 182-183). In terms of food symbolism, the gull's eating leftovers is linked to Lev's disappointment and feeling of being refused and thrown away by Sophie's remark as if he were rubbish. 
In symbolic terms, Lev's position in this love affair is characterized by an initial desired food, an interstitial tasty dish and a final state of thrown-away breadcrumbs. Sophie thus symbolically expends Lev, rendering him from a highly-valued delicious food to waste. This symbolic expenditure resembles the effects of the capitalist faith that attaches value to material being fully aware of the non-objective, non-innate and not materially-defined nature of that value. Although Lev never conceptualizes this symbolism of sexuality, when Sophie leaves him for a fashionable celebrity, his frustration may be attached to his abhorrence at consumer society's 'take it, use it, throw it' attitude.

This consumerism is rooted in attaching symbolic value to material. Lev, when encountering it in the form of attaching positive value to simple meals, passionately admires this suspension of disbelief. However, when it is directed against him, he somehow finds the attitude disgusting. There is a dynamic of the encounter with the 'other' also involved here. Sophie is deliberately depicted as an exotic dish. Her otherness first attracts him with all its consequences, whereas, later, he finds the British consumerist attitude repulsive. Their final violent sexual intercourse is also meant to indicate Lev's vengeful reciprocation of the exploitation and consumerist degradation of value that he had suffered from the girl. What Lev is experiencing here is not far from the phenomenon that is a traditional object of capitalist anxieties regarding precisely the value of work and the corresponding objectification of the person who does the work. The Marxian alienation is closely linked to consumerism which renders people material whose value can be set in consumerist terms. This happens to Lev and that is why he attempts to seek revenge on Sophie by raping her, calling her a whore, which is a classic degradation of value in consumerist terms. Then he desperately engages in nationalist denigration calling all English girls "racist, promiscuous, shameless" (Tremain 2007, 241). This is the lowest point in the novel concerning the cooperation of the hetero- and auto-image in order to achieve a fertilizing effect of one image on the other. However, by the end of the book, Lev slowly and reluctantly learns his lessons in the capitalist faith.

\section{Art, representation, value relativism}

The discourse of suspended disbelief is not only a characteristic of capitalism, but it is strongly present in artistic representation, as it is claimed by Greenblatt (2000, 163). A characteristic British auto-image in the novel is attached to postmodern theatre. Young dramatists among Sophie's friends appal Lev with a theory one of them reveals to him on a party. The English dramatist suggests that true progressive English theatre, after the period of the $20^{\text {th }}$-century kitchen sink drama, should now turn towards the loo. This is meant as a symbolic gesture 
of deconstructing what civilizational dreg is buried there. In the context of the social reality where real loos are mostly cleaned and mended by immigrants and not the English, this theory sounds ironic. But this irony is felt neither by the English theatre community, nor by Lev, the immigrant.

Together with Sophie, Lev finally sees such a naturalist 'loo' play about a paedophile father. The artist friends hail the drama for its subtle and sharp representation of reality. In contrast, Lev is outraged by its arty manners, and feels hurt in his fatherly affection. For him, like for most immigrants in London, the disgusting side of the flesh, such as excrement or some unnatural sexual desire, is neither disgusting nor a subject of art. It seems that he is unable to decode artistic, mimetic signification in such a postmodern artwork. He takes it at face value. His indignation at the play culminates in an uncontrolled rage against the whole artificial world created by the suspended disbelief of art, by the capitalist faith, by what he gradually understood as Britain, as the West. He greatly admired all of this and wanted to share it earlier, but it repeatedly seemed to refuse him and his mentality. István Fried's notion of 'Hassliebe' may also be illuminating here (Fried 2000), as there is a simultaneous attraction and repulsion in Lev's relation to the Western centre.

Turning against a world perceived unreal is a key element in his fury: "he knew he should have tried to master his feelings, but why master feelings that, in this unreal world he'd just entered, felt real and true?” (Tremain 2007, 210). In imagology, it is an often-described phenomenon that the culture of the other is perceived as unreal. This is an attempt at preserving the purity and inherent originality of one's own culture, which has the impression of being threatened by encountering the 'other'. As claiming the 'other' unreal mostly occurs in situations of cultural interaction, it seems to be a function of what Homi Bhabha terms the enunciatory Third Space, where cultures no longer exist in isolation but in organic fluctuation (Bhabha 1994, 37). In this sense, Lev's deep frustration is not only directed against what he experiences as the other in artistic representation as well as in capitalist faith. His rage is also directed against his own self which is involved in and wants to take part in this culture. In light of this, his desperate drunken ravaging in the streets when he spills out waste and rubbish onto the pavement and shouts: "I've made my life obscene" (Tremain 2007, 215) are understandable. He himself, as a would-be capitalist, a new believer in symbolic values participated in rendering his own post-socialist mentality ridiculous and his own life obscene. Two selves are raging in Lev. Two different attitudes, on the one hand, Western art conception and, on the other hand, East-Central European thinking are pitted against each other. What is art for Britain, the capitalist Lev and refined chef is reality for Lev, the immigrant and East-Central European.

Such a portrayal of the East-Central European may be associated with what Joep Leerssen calls primitivism: an exoticist image of the periphery as innocent 
and authentic (Leerssen 2007, 407). The Road Home is often criticized by its primitivist, exoticist, or even orientalist portrayal of East-Central Europe. Józef Jaskulski goes as far as suggesting that Lev is an accumulation of features earlier represented by literary figures such as Caliban and Friday (Jaskulski 2009, 3). Although I think that Lev's character is much more complex and it is portrayed in the very turmoil of the Bhabhaian enunciatory site of culture as opposed to Jaskulski's idea of him as a simplistic and essentialized brute, orientalist charges also have basis. The book's depiction of East-Central Europe may be situated in orientalist traditions of portraying the margin in feminized passivity as Corina Crisu claims (Crisu 2010, 373). Moreover, Lev's country is mostly represented as a pastoral world. As Jaskulski claims, it appears as a unified rural post-communist conglomerate with unskilled manual labourers and party members to oppress them (Jaskulski 2009, 5). However, there are important characters who tinge this picture, such as Vitas, who is a university student, Lydia, the teacher and Maestro Greszler, the great conductor. What is more, the charge of orientalistically-fixed characteristics of the cultures of East and West could be refuted by the whole narrative which is after all a story of identity in transition. I think that aside from the distinctly present stereotypical portrayal, the novel is a subtle saga about the operation of the very stereotypes it seems to be finally unable to evade entirely. The most important illustration of this is Lev's personal development which cannot be simplified as a learning process, because characteristics that Lev develops throughout his stay in London cannot be attributed only to the influence of British culture. Some are already present in Lev, such as the promise of self-fulfilling belief, which is mostly facilitated by the encounter with the capitalist 'other' though.

However, the Bildungsroman line of the narration is still often criticized from an imagologist point of view. Critics, such as Julia Elena Thiel, disapprove of the novel's fairy-tale like, rags-to-riches archetype structure (Thiel 2014, 215) which allows the narrative to end in only the hetero-image being affected by the auto-image, and only a few, if any, reciprocal interaction happening as also pointed out by Kathleen Starck $(2013,66)$. By the end of the book, Lev seems to internalize the condition of crediting value to material attributed in the novel mostly to the capitalist West. This is what is manifested in his obsession to open a progressive restaurant, which he successfully does. This closing part has been widely criticized as an orientalist moment of civilizing mission (Jaskulski 2009, 215 and Starck 2013, 59), which is mostly the case indeed. Lev is about to teach his fellow countrymen the lesson he has learnt in England. He wishes to transport the condition of crediting value to simple material and thus elevating it.

An episode from the last scenes of the novel exemplifies it well. Lev and his best friend stare at a newly-opened modern art gallery in their hometown. His friend is outraged by a statue made of car components, and says, evoking Lev's 
outrage at the drama: "I spent my fucking life going in search of auto-parts. I lay awake at night worrying myself to death. And now what? Some arsehole sculptor just squanders them - as though they had no value. As though nothing had any value anymore." To this culture shock at the material's symbolic value, the already-changed Lev answers: "How has anyone ever been able to calculate value? Only by the price people are prepared to pay" (Tremain 2007, 360). Again, we see the problem of food and waste. Auto-parts, which are considered valuable by Rudi, are also valued by the artist, but on another level, because of other characteristics that are not directly rooted in their practical value. At this illuminating moment of the book, capitalist ideology, Western food culture, and artistic representation all culminate in a new perspective for the protagonist. The attitude that attaches value to material, let that be a combination of food, paper money or auto parts, leads way to the Western-originated mentality which is aware of the non-objectively given nature of its own categories.

\section{Conclusion}

Rose Tremain's The Road Home is a culture shock narrative in Bildungsroman fashion. It presents the encounter of the British auto- and the East-Central European hetero-image through the complex symbolism centred on images of food, consumption and waste. These materialistic problems are put on an ideological level by Stephen Greenblatt's seminal essay on Hamlet, an intertextual kin to Tremain's protagonist. Reading The Road Home through Greenblatt's reading of Hamlet is illuminating as to the wide scope of meanings in which this cultural interaction is depicted in this novel. This reading opens up various meanings attached to the symbol of food, which appears as a simple signifier meaning identity to some critics, such as Anna Maria Tomczak (2013, 456). Instead of being a simple signifier, the symbolic meaning of food has Renaissance roots which reveal its interrelatedness with Christian faith, later capitalist credit as well as Christian-originated anxieties concerning excrement and later capitalist anxieties concerning the exploitation and objectification of people.

Through gaining an insight into Western food culture, Lev grasps an important element from the underlying structure of what is portrayed as capitalist mentality. What is a cathartic intercultural experience for Lev is the representational thinking which is a common element in the "beautiful food" of modern cuisine, in capitalist faith, and in artistic representation. What Lev learns as part of a fictional British civilizing mission is attributing value to material.

The fact that the novel presents this gesture as typically Western renders the portrayal undeniably orientalist. However, the book's presentation of the culture clash is aware of non-essentialist elements of identity as well. Lev's development 
of personality happens under the strong influence of the British auto-image, but the characters from the two cultural milieus are portrayed as more subtle and less-culturally coded. Moreover, the protagonist's transition is far from being utter and uncritical. Conclusively, the novel shows the blending of two cultures in most complex ways, being aware of the radical differences between British and East-Central European cultural heritage and some of the painful lessons that both parties have to learn during such a process. The interwoven symbols of food, material, capitalism and artistic representation are at the core of this representation and they have an illuminating effect in depicting fundamental elements of this culture clash.

\section{Works cited}

Bhabha, Homi K. 1994. The Location of Culture. London: Routledge.

Crisu, Corina. 2010. British Geographies in the Eastern European Mind: Rose Tremain's The Road Home. In Facing the East in the West: Images of Eastern Europe in British Literature, Film and Culture, eds. Barbara Korte, Eva Ulrike Pirker, Sissy Helff, 365-379. New York: Rodopi.

Fried István. 2012. Imagológiai kérdések - Komparatisztikai kétségek. [Imagological Questions, Comparatistic Doubts.] In Bevezetés az összehasonlító irodalomtudományba. [Introduction into Comparative Literature.] 189-215. Budapest: Lucidus Kiadó.

Fried István. 2000. A „freudizmus” - ahogy Márai elgondolta. [“Freudism” as Márai conceptualized it.] Forrás vol. 32 no. 4: 26-37. http://www.forrasfolyoirat.hu/0004/fried.html (14 May 2015)

Greenblatt, Stephen. 2000. The Mousetrap. In Practicing New Historicism, eds. Catherine Gallagher and Stephen Greenblatt, 136-163. Chicago: University of Chicago Press.

Jaskulski, Józef. Friday Reeducated: Orientalizing the East-Central European Other in Rose Tremain's The Road Home. http://www.inter-disciplinary.net/wpcontent/uploads/2009/08/jozef-jaskulski-tremain-paper.pdf. (22 April 2015)

Leerssen, Joep and Manfred Beller, eds. 2007. Imagology - The Cultural Construction and Literary Representation of National Characters: A Critical Survey. Amsterdam: Rodopi.

Starck, Kathleen. 2013. A Lot of Catching Up to Do - The West as a Civiliser of PostCold War Eastern Europe in Rose Tremain's The Road Home. In From Popular Goethe to Global Pop - The Idea of the West between Memory and Empowerment, eds. Ines Detmers and Birte Heidemann, 55-70. Amsterdam: Rodopi. 
Thiel, Julia Elena. 2014. "A Man May Travel Far”: Eastern European Labour Migration as a Quest for Masculine Self-Assertion in Rose Tremain's The Road Home. In Verorten - Verhandeln - Verkörpern: Interdisziplinäre Analysen zu Raum und Geschlecht, eds. Silke Förschler, Rebekka Habermas, Nicola Roßbach, 197-218. Bielefeld: Transcript Verlag.

Tomczak, Anna Maria. 2013. Trying to Cross Frontiers of Fortress Europe - Rose Tremain's Novel: The Road Home. In Crossroads in Literature and Culture, eds. Jacek Fabiszak, Ewa Urbaniak Rybicka, Bartosz Wolski, 451-461. Berlin: Springer Verlag.

Tremain, Rose. 2007. The Road Home. London: Vintage Books. 